\title{
ANALISIS EKONOMI USAHA PENANGKAPAN UDANG LAUT (PENAEID) DAN PEMASARANNYA DI PANTAI UTARA JAWA
}

\author{
Manadiyanto"), Sastrawidjaja*), Sapto Adi Pranowo") dan Tony Sudarmanto*)
}

\section{ABSTRAK}

Usaha penangkapan udang penaeid di pantai utara Jawa terus berlangsung dengan alat tangkap utama adalah jaring tiga lapis, jaring arad dan rampus. Hasil penelitian menunjukkan bahwa usaha penangkapan udang penaeid masih belum memberikan tingkat kesejahteraan khususnya bagi nelayan penggarap. $\mathrm{Hal}$ ini dipengaruhi oleh sistim bagi hasil dan sistem pasar udang yang dikuasai oleh lembaga pasar tertentu. Alternatif pengembangan model pusat bisnis udang penaeid merupakan solusi yang bisa meningkatkan tingkat kesejateraan nelayan.

\section{ABSTRACT: Economic Analysis of Shrimp Fishery and Marketing in the North Coast of Java. By: Manadiyanto, Sastrawidjaja, Sapto Adi Pranowo and Tony Sudarmanto.}

\begin{abstract}
Shrimp (penaeid) fishery in north coast of Java have been continously practiced with dominant fishing gears of trammel net and mini trawlers. Result of the study shows, that shrimp penaeid fishery do not able to provide a sufficient welfare level, especially to fishers. This happens because the overall system was influenced by sharing system and shrimp market system which is dominanted by the market institution activities.An alternative solution is to develop the business center of shrimp penaeid by which fishers welfare status may enable be improved.
\end{abstract}

KEYWORDS: economic analysis, shirmp fishery, marketing, North Coast of Java

\section{PENDAHULUAN}

Kesteven, G.L. (1973) dalam Nurani (1991) menyatakan bahwa suatu usaha penangkapan perikanan laut haruslah ditinjau melalui pendekatan bio-technico-socioeconomic approach. Terkandung maksud bahwa pengelolaan terhadap usaha penangkapan perikanan haruslah mempertimbangkan aspek biologi, aspek teknis, aspek sosial dan aspek ekonomi. Aspek tersebut tidak dapat dipisahkan antara yang satu dengan lainnya dalam menentukan arah kebijakan dan pengembangan usaha perikanan udang penaeid

Pertimbangan aspek biologi yaitu dengan memperhatikan faktor-faktor kelestarian sumberdaya. Aspek teknis menggambarkan usaha dengan memperoleh metode yang efektif dan efisien disertai dengan ketersediaan fasilitas yang dapat menunjang kelancaran operasional. Aspek sosial mencakup gambaran suatu usaha yang dapat diterima masyarakat, dapat meningkatkan taraf hidup dan tidak menimbulkan keresahan di masyarakat. Aspek ekonomi menggambarkan usaha penangkapan merupakan kegiatan ekonomi yang bertujuan untuk mendapatkan keuntungan usaha disamping diperlukan juga adanya jaminan kelangsungan usaha berupa tersedianya sarana fisik non fisik yang merupakan prasyarat bagi perkembangan ekonomi.

Sampai saat ini udang masih menjadi salah satu komoditi terpillih yang memiliki nilai ekonomi tinggi, hal ini terlihat dari permintaan di pasaran dunia yang terus meningkat sedangkan disisi lain ekspor udang Indonesia terus mengalami penurunan, yang berarti bahwa untuk memenuhi kebutuhan pasar dunia masih sangat jauh tidak mencukupi sebagai gambaran tahun 1992-1993 ekspor udang Indonesia mengalami penurunan 3\% dari 13.769 ton menjadi 13.330 ton. Ekspor udang Indonesia baru bisa memenuhi kebutuhan pasar Amerika sebesar 4\%.

Daerah penangkapan udang penaeid tersebar diperairan Indonesia, salah satunya adalah pantai utara Jawa. Perikanan udang di pantai utara Jawa hampir terdapat di sepanjang pantai terutama dekat muara-

Pusat Riset pada Pengolahan Produk dan Sosial Ekonomi Kelautan dan Perikanan 
muara sungai. Habitat hidupnya cukup luas, walaupun daerah tidak banyak bermuara sungai besar seperti di Kalimantan dan Sumatera tetapi jumlah sungai kecil cukup banyak sehingga mampu memberikan kesuburan perairan ini. Produksi nasional udang penaeid tahun 1997 sebesar 208.231 ton, sedangkan produksi di pantai utara Jawa sebesar 18.222 ton, yang berarti baru memberikan kontribusi produksi sebesar $8 \%$ terhadap produksi nasional. Kecilnya produksi ini memacu pengusaha baik yang bergerak dibidang budidaya maupun penangkapan melakukan pengembangan usaha untuk meningkatkan produksinya.

Suatu terobosan dalam
penangkapan udang penaeid pernah
dilakukan pada era trawl. Tetapi karena pertimbangan-pertimbangan sosial dan kelestarian sumberdaya maka penggunaan trawl dilarang beroperasi di perairan Sumatera, Jawa dan Bali (Keppres No.38/1980). Sejak itu pula alat tangkap jaring trammel net (jaring tiga lapis) dianggap paling layak sebagai alat pengganti trawl untuk menangkap udang penaeid, meskipun ratarata daya tangkap alat tangkap ini 1/40 dari daya tangkap trawl (Azis,1996). Jaring tiga lapis (trammel net) diharapkan menjadi solusi masalah sosial yang terkait dengan penggunaan trawl, yaitu dengan memberi tempat yang baik bagi nelayan skala kecil karena biaya investasi dapat terjangkau oleh nelayan.

Sejalan dengan salah satu tujuan pembangunan perikanan laut yaitu untuk meningkatkan taraf hidup nelayan maka perlu adanya pengamatan terhadap perkembangan kondisi usaha untuk mengidentifikasi masalah dan menemukan solusinya. Solusi tersebut diperlukan untuk peningkatan pendapatan nelayan, pemenuhan kebutuhan rumah tangga nelayan, maupun untuk pengembangan usahanya.

Tujuan tulisan ini untuk mengetahui perkembangan kondisi usaha dan distribusi pemasaran udang penaeid di pantai utara Jawa, sedangkan kegunaannya sebagai bahan masukan bagi pembuat kebijakan di bidang perikanan laut.

\section{METODE}

Penelitian ini dilakukan selama tahun anggaran 2001 di sepanjang pantai utara Jawa penghasil udang penaeid yaitu Desa
Mayangan (Subang), Desa Wedung (Demak), Desa Banyutowo (Pati) dan Desa Pesisir (Gresik). Lokasi tersebut dipilih karena merupakan penghasil udang utama di wilayahnya. Data primer dikumpulkan melalui wawancara berstrukur terhadap nelayan udang. Disamping itu dilakukan wawancara terhadap pedagang untuk mengetahui jalur distribusi pemasaran udang di pantai utara Jawa.

Untuk mengetahui kondisi usaha penangkapan udang penaeid dilakukan analisa partial budgeting (Amir dan Knipscheer, 1989 dalam Priyanti, et al., 2000) sedangkan distribusi pemasaran menggunakan analisis Market Structure, Market Conduct dan Market Performance. Sedangkan data yang sifatnya kuantitatif dilakukan analisa deskriptif.

\section{HASIL DAN PEMBAHASAN}

\section{Gambaran Umum Perikanan Udang Penaeid di pantai utara Jawa.}

Pantai utara Jawa sampai saat ini merupakan salah satu perairan penghasil udang penaeid terpenting terutama di Indonesia. Meskipun kontribusinya terhadap produksi nasional udang penaeid masih relatif rendah yaitu $8 \%$, penyerapan jumlah nelayan yang terlibat di dalamnya relatif besar dan nilai produksinya juga cukup besar.

Jenis udang yang tertangkap di pantai utara Jawa didominasi oleh udang windu (Penaeus monodon), udang jerbung (Penaeus merguensis), udang dogol (Metapeneus ensis) dan udang lainnya (udang krosok) yang pada umumnya tertangkap di pantai yang berdekatan dengan muara sungai.

Produksi yang dihasilkan cukup berfluktuatif. Statistik 20 tahun terakhir menunjukkan bahwa produksi terendah terjadi pada tahun 1981 yaitu sebesar 8.073 ton. Ini terjadi karena pada tahun 1980 baru saja diberlakukannya Keppres $39 / 1980$ pelarangan trawl, dan produksi tertinggi pada tahun 1992 yaitu sebesar 16.628 ton. Produksi ini diperoleh dari berbagai alat tangkap udang, termasuk lampara, dogol (danish seine), pukat pantai (beach seine), jaring klitik (shrimp gill net), jaring lapis tiga (trammel net), jaring insang tetap (set gill net) dan sero (barrier trap). Dari tujuh jenis alat yang bisa menangkap udang, jaring trammel net merupakan alat tangkap standar dengan 
alasan alat ini menghasilkan jumlah tangkapan udang yang relatif besar dari pada alat tangkap udang lainnya. Berdasarkan jumlah produksi yang dihasilkan dan jumlah alat tangkap udang penaeid yang beroperasi di pantai utara Jawa menunjukkan tingkat pemanfaatan udang penaeid belum optimal. Rata-rata prosentase pengusahaannya masih berkisar antara $28 \%-79 \%$ yang berarti bahwa dengan peningkatan produksi penambahan alat tangkap masih dimungkinkan (Hudha, dan Hendra, 2000).

Jumlah nelayan yang berada di pantai utara Jawa tahun 1997 berjumlah 475.691 orang, terdiri dari nelayan penuh (full time) 299.525 orang, nelayan sambilan utama (part time,mayor) 130.227 orang dan nelayan sambilan tambahan (part time, minor) 45.939 orang. Jumlah nelayan ini berprofesi sebagai nelayan dari berbagai jenis alat tangkap yang ada di pantai utara Jawa,sedangkan nelayan khusus yang menangkap udang sampai saat ini masih belum teridentifikasi.

\section{Sistim Bagi Hasil}

Seperti umumnya berlaku dalam usaha penangkapan perikanan laut skala kecil, sitem upah yang berlaku pada usaha penangkapan udang adalah sistim bagi hasil. Tidak satu pun dari usaha penangkapan udang skala kecil yang melakukan upah dengan sistem gaji. Ini terjadi karenaa adat kebiasaan masyarakat setempat. Meskipun sistem bagi hasil dalam usaha penangkapan perikanan laut sudah diatur dalam Undangundang Pokok Bagi Hasil (UUPBH) No.16 tahun 1964, tapi tidak ada satupun daerah di pantai utara Jawa yang memberlakukan sistim bagi hasil berdasarkan undang-undang tersebut. Ini terjadi karena disamping UUPBH No.16/1964 ini tidak pernah ada petunjuk operasionalnya juga tidak pernah di sosialisasikan.

Sesungguhnya undang-undang tersebut bertujuan untuk meningkatkan taraf hidup para nelayan penggarap, sehingga dapat diharapkan (a) pembagian hasil tangkapan antara juragan sebagai pemilik dan nelayan penggarap dilakukan atas keadilan, (b) dengan penegasaan hak-hak kewajiban nelayan pemilik dan penggarap terjamin kedudukan hukum yang jelas dan layak bagi nelayan penggarap yang biasanya dalam pelaksanaan bagi hasil berada pada kedudukan yang lemah, dan (c) untuk meningkatkan kegairahan kerja para penggarap sehingga berpengaruh baik terhadap pemeliharaan alat penangkapan.

Dalam undang-undang tersebut diatur mengenai pembagian hasil (pasal 3 ayat 1), bentuk perjanjian, jangka waktu perjanjian (pasal 7 ayat 1) dan pembebanan tanggungan (pasal 4 ayat 1). Dalam pembagian hasil disebutkan bahwa jika dalam suatu penangkapan diselenggarakan atas perjanjian bagi hasil maka dari hasil usaha itu kepada pihak nelayan diberikan paling sedikitnya $75 \%$ dari hasil bersih bila menggunakan perahu layar, dan $40 \%$ dari hasil bersih bila menggunakan perahu motor. Bentuk perjanjian sebaiknya dilakukan secara tertulis dan jangka waktu perjanjian paling sedikit satu tahun. Beban biaya yang menjadi tanggungan bersama antara pemilik dengan penggarap selama penangkapan antara lain ongkos lelang, uang rokok/jajan, biaya untuk sedekah laut,koperasi dan dana kematian. Sedangkan yang menjadi tanggungan nelayan pemilik yaitu ongkos pemeliharaan dan perbaikan, biaya penyusutan dan biaya eksploitasi (olie,es dan bahan bakar).

Hasil penelitian menunjukkan bahwa dalam usaha penangkapan udang di beberapa daerah Subang, Demak, Pati dan Gresik, sistim upah dengan cara bagi UUPBH melainkan pada adat kebiasaan masyarakat didaerah tersebut. Bisa saja diantara daerah sistim bagi hasil yang berlaku berbeda antara daerah satu dengan lainnya namun adakalanya bagi hasil yang berlaku sama diantara daerah tersebut. Seperti halnya alat tangkap trammel net maupun arad perolehan pendapatan dibagi dari hasil bersih menjadi lima bagian yaitu pemilik 1 bagian, pendega 1 bagian, kapal, mesin dan alat tangkap masing-masing 1 bagian, yang berarti pendapatan pendega hanya $1 / 5$ atau $20 \%$ masih dibawah ketentuan yang ditetapkan oleh UUPBH.Hal ini terjadi diseluruh daerah penelitian Subang, Demak, Pati dan Gresik (Gambar 1).

Bila dilihat dari sistim pembebanan tanggung jawab atas biaya penangkapan udang penaeid di pantai utara Jawa, terlihat bahwa ada beban tanggung jawa biaya yang seharusnya menjadi tanggung jawab pemilik dalam pelaksanaannya menjadi beban tanggung jawab bersama. Begitu pula dalam hal bentuk perjanjian bagi hasil yang tidak dilakukan secara tertulis dan hanya dilakukan 


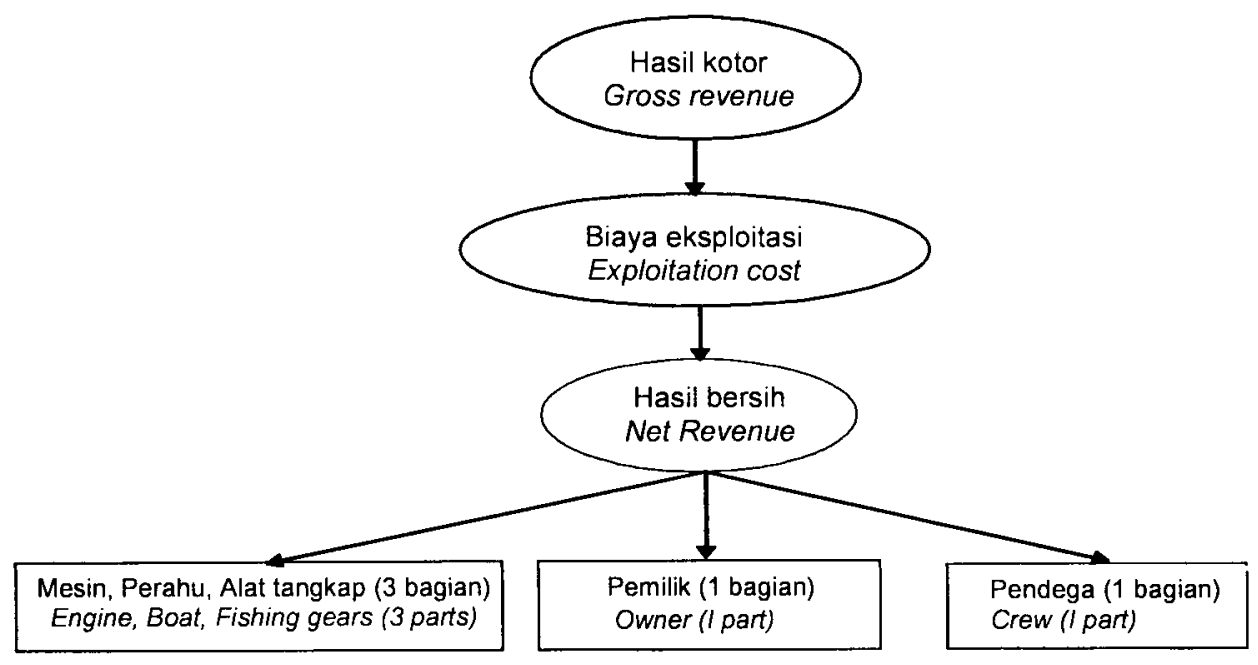

Gambar 1. Sistim bagi hasil alat tangkap udang penaeid di pantai utara Jawa

Figure 1. Sharing system of shrimp fishery in north coast of Java

secara lisan. Hal ini didorong oleh rasa saling percaya diantara kedua belah pihak dan kesepakatan yaitu bahwa pemilik dan penggarap tidak ingin berbelit-belit dalam melakukan perjanjian bagi hasil. Ini menunjukkan adanya kesederhanaan dalam berfikir.

Jangka waktu perjanjian dalam pelaksanaannya tidak ditentukan dan tidak terbatas, sehingga bisa terjadi pemutusan kerja sepihak baik datangnya dari pihak pemilik maupun dari pihak penggarap. Pemutusan hubungan kerja datangnya dari pemilik bila penggarap dianggap tidak memenuhi ketentuan yang sudah disepakati ataupun dianggap tidak terampil dan kurang menghasilkan. Pemutusan hubungan kerja dari penggarap terjadi pada musim udang, dimana nelayan penggarap yang bersangkutan pindah ke juragan lain untuk mendapatkan bagian hasil yang lebih besar dari juragan sebelumnya.

Dalam kenyataan lapangan, pembebanan tanggungan yang dikeluarkan dalam penangkapan dibagi bersama dengan cara memotong dari hasil kotor yang diperoleh dari hasil tangkapan. Tabel 1 , menunjukkan bahwa sebagian dari sistem pembebanan tanggung jawab atas biaya penangkapan udang penaeid di pantai utara Jawa tidak sesuai dengan ketentuan UUPBH yaitu biaya ekploitasi yang seharusnya menjadi tanggungan pemilik namun dalam pelaksanaannya menjadi tanggungan bersama. Begitu pula dalam hal bagi hasil dimana pemilik mendapatkan $80 \%$ sedangkan penggarap/ pendega memperoleh $20 \%$. Antara pelaksanaan dan UUPBH terjadi perbedaan sebesar $20 \%$ dimana dalam hal ini penggarap/pendega dirugikan. Meskipun keadaan ini telah berlangsung lama dan sangat merugikan nelayan penggarap/ pendega, pelaksanaan bagi hasil yang demikian masih tetap terus berlangsung.

Ada beberapa kemungkinan yang menyebabkan pelaksanaan UUPBH ini tidak berjalan yaitu (a), belum tahunya nelayan akan keberadaan undang-undang yang mengatur pelaksanaan sistim bagi hasil karena tidak tersosialisasikan, (b), nelayan penggarap/pendega berada dalam pihak yang lemah sehingga tidak berani melakukan tuntutan dan (c), kuatnya peran pemilik karena nelayan penggarap/ pendega memiliki posisi tawar (beginning position) yang lemah.

Sesungguhnya pelaksanaan sistim bagi hasil dilaksanakan berdasarkan adat kebiasaan setempat tidak dilarang asalkan tidak merugikan nelayan pendega dalam hal beșarnya hasil yang harus diterima maupun beban biaya operasional penangkapan yang harus ditanggung.

\section{Analisa Ekonomi Usaha Penangkapan Udang}

\section{Investasi}

Kajian analisa usaha pada setiap jenis usaha yang melibatkan modal, tenaga kerja dalam proses produksi dalam sektor jasa, industri maupun pertanian (perikanan tangkap) sangat perlu dilakukan dengan maksud untuk mengetahui sampai sejauh 
Tabel 1. Tanggung jawab atas biaya penangkapan udang penaeid di beberapa daerah di utara Jawa

Table 1. Responsibility on cost shrimp capture in several region in north Java

\begin{tabular}{|c|c|c|c|c|c|}
\hline \multirow{2}{*}{$\begin{array}{l}\text { Beban tanggung } \\
\text { jawab atas biaya } \\
\text { penangkapan udang } \\
\text { (Responsibility on } \\
\text { cost shrimp capture) }\end{array}$} & \multicolumn{4}{|c|}{ Kabupaten (Regency) } & \multirow{2}{*}{$\begin{array}{c}\text { UUPBH } \\
\text { No.16/1964 } \\
\text { (Act of } \\
\text { Sharing } \\
\text { system } \\
\text { fisheries) }\end{array}$} \\
\hline & Subang & Demak & Pati & Gresik & \\
\hline $\begin{array}{l}\text { Biaya Lelang/ } \\
\text { Retribution }\end{array}$ & $\begin{array}{l}\text { Bersama/ } \\
\text { Joint venture }\end{array}$ & $\begin{array}{l}\text { Bersamal } \\
\text { Joint venture }\end{array}$ & $\begin{array}{l}\text { Bersamal } \\
\text { joint venture }\end{array}$ & $\begin{array}{l}\text { Bersamal } \\
\text { Joint venture }\end{array}$ & $\begin{array}{l}\text { Bersama/ } \\
\text { Joint venture }\end{array}$ \\
\hline $\begin{array}{l}\text { Rokok/Jajan/ } \\
\text { Cigarette }\end{array}$ & $\begin{array}{l}\text { Bersama/ } \\
\text { Joint venture }\end{array}$ & $\begin{array}{c}\text { Bersamal } \\
\text { Joint venture }\end{array}$ & $\begin{array}{c}\text { Bersamal } \\
\text { Joint venture }\end{array}$ & $\begin{array}{l}\text { Bersamal } \\
\text { Joint venture }\end{array}$ & $\begin{array}{c}\text { Bersamal } \\
\text { Joint venture }\end{array}$ \\
\hline $\begin{array}{l}\text { Koperasi dan dana } \\
\text { kematian/ } \\
\text { Cooperation and live } \\
\text { insurance }\end{array}$ & $\begin{array}{l}\text { Bersama/ } \\
\text { Joint venture }\end{array}$ & $\begin{array}{l}\text { Bersamal } \\
\text { Joint venture }\end{array}$ & $\begin{array}{l}\text { Bersama/ } \\
\text { Joint venture }\end{array}$ & $\begin{array}{l}\text { Bersama/ } \\
\text { Joint venture }\end{array}$ & $\begin{array}{c}\text { Bersamal } \\
\text { Joint venture }\end{array}$ \\
\hline $\begin{array}{l}\text { Sedakah laut/ } \\
\text { Social fee }\end{array}$ & $\begin{array}{l}\text { Bersama/ } \\
\text { Joint venture }\end{array}$ & $\begin{array}{l}\text { Bersamal } \\
\text { joint venture }\end{array}$ & $\begin{array}{l}\text { Bersamal } \\
\text { Joint venture }\end{array}$ & $\begin{array}{l}\text { Bersamal } \\
\text { Joint venture }\end{array}$ & $\begin{array}{l}\text { Bersamal } \\
\text { Joint venture }\end{array}$ \\
\hline $\begin{array}{l}\text { Pemeliharaan/ } \\
\text { Maintenance }\end{array}$ & Pemilik/owner & Pemilik/owner & Pemilik/owner & Pemilik/owner & Pemilik/owner \\
\hline $\begin{array}{l}\text { Penyusutan/ } \\
\text { Depretiation }\end{array}$ & Pemilik/owner & Pemilik/owner & Pemilik/owner & Pemilik/owner & Pemilik/owner \\
\hline $\begin{array}{l}\text { Biaya Eksploitasi/ } \\
\text { Exploitation cost }\end{array}$ & $\begin{array}{l}\text { Bersama/ } \\
\text { Joint venture }\end{array}$ & $\begin{array}{l}\text { Bersama/ } \\
\text { Joint venture }\end{array}$ & $\begin{array}{l}\text { Bersama/ } \\
\text { Joint venture }\end{array}$ & $\begin{array}{l}\text { Bersamal } \\
\text { Joint venture }\end{array}$ & $\begin{array}{l}\text { Bersamal } \\
\text { Joint venture }\end{array}$ \\
\hline $\begin{array}{l}\text { Bagi hasil } \\
\text { (Sharing System): } \\
\text { Pemilik/Owner (\%) } \\
\text { Pendega/Crew (\%) }\end{array}$ & $\begin{array}{l}80 \\
20\end{array}$ & $\begin{array}{l}80 \\
20\end{array}$ & $\begin{array}{l}80 \\
20\end{array}$ & $\begin{array}{l}80 \\
20\end{array}$ & $\begin{array}{l}60 \\
40\end{array}$ \\
\hline
\end{tabular}

mana usaha itu dapat memberikan tingkat manfaat yang dicirikan dengan tingkat keuntungan, sehingga menjadi pedoman untuk pengembangkan usaha selanjutnya.

Usaha penangkapan udang dipantai utara Jawa menunjukkan bahwa investasi per unit usaha dibeberapa daerah cukup beragam. Di Kabupaten Subang (Jawa Barat) investasi untuk alat tangkap trammel net sebesar $R p$. 12.690.000,-, jaring arad sebesar Rp. $11.500 .000,-$ dan jaring rampus sebesar $R p$. 12.190.000,-. Dari besarnya investasi ini komponen terbesar pada alat trammel net diserap oleh biaya pembelian kapal $63 \%$, mesin $19,7 \%$, jaring tramel net $11,8 \%$, perlengkapan kapal $2,8 \%$ dan perlengkapan mesin $2,7 \%$. Sedangkan pada alat tangkap jaring arad, kapal menyerap modal terbesar yakni $69,9 \%$, mesin $21,7 \%$ dan alat tangkap $2,6 \%$, sedang perlengkapan kapal $2,6 \%$ dan perlengkapan mesin $2,9 \%$. Sedangkan alat tangkap rampus kapal menyerap $65,6 \%$, mesin $20,5 \%$, jaring rampus $8,2 \%$, perlengkapan kapal $2,8 \%$ dan perlengkapan mesin 2,7\%.

Di Kabupaten Demak (Jawa Tengah), usaha penangkapan udang penaeid menggunakan alat tangkap trammel net dan jaring arad. Investasi kedua alat tersebut masing-masing untuk trammel net sebesar Rp.14.970.000,- dan jaring arad sebesar Rp. 12.495.000,- . Untuk jaring trammel net modal terbesar diserap oleh kapal mencapai $60,12 \%$, mesin $16,70 \%$ dan jaring trammel net $16,70 \%$, untuk perlengkapan kapal 3,17\%, perlengkapan mesin 2,97\% dan perlengkapan penanganan hasil $0,34 \%$. Sedangkan untuk jaring arad perahu menyerap modal terbesar yaitu $68,02 \%$, mesin $20 \%$ dan alat tangkap $4,80 \%$, perlengkapan kapal menyerap $3,20 \%$ dan perlengkapan mesin $3,56 \%$ serta pelengkapan penanganan hasil $0,40 \%$. 
Di Kabupaten Gresik (Jawa Timur) hanya terdapat satu alat tangkap yang digunakan untuk menangkap udang penaeid yaitu jaring trammel net. Investasi per unit penangkapan sebesar Rp. 18.950.000,-. Modal terbesar diserap kapal dan mesin masing-masing $42,21 \%$, jaring menyerap $10,55 \%$, pelengkapan kapal 2,09\%, perlengkapan mesin $2,83 \%$ dan perlengkapan penanganan hasil $0,51 \%$.Di Kabupaten Pati, inventasi per unit jaring trammel net sebesar Rp. 11.300.000,terdiri dari perahu/kapal $66,37 \%$, alat $13,28 \%$ dan mesin $20,35 \%$.

Dari uraian diatas dapat disimpulkan bahwa investasi terbesar dalam penangkapan uadang penaeid di pantai utara Jawa didominasi oleh kapal, mesin dan jaring berkisar antara $80 \%-90 \%$ dari seluruh investasi, sedangkan perlengkapan kapal, perlengkapan mesin dan perlengkapan penanganan hasil berkisar antara $0,5 \%-10 \%$.

\section{Biaya}

Ada dua jenis biaya yang harus dikeluarkan dalam suatu usaha penangkapan perikanan di laut yaitu biaya tetap (fixed cost) dan biaya tidak tetap (variable cost). Defenisi dari biaya tetap adalah semua biaya yang dikeluarkan tetap setiap tahunnya seperti biaya penyusutan (depreciation cost), biaya adminstrasi (surat izin berlayar, surat pas). Sedangkan biaya tidak tetap adalah biaya yang dikeluarkan setiap kali proses produksi, seperti bahan bakar (solar, olie, minyak tanah), ransum, es dan biaya pemeliharaan (Nikijuluw, 1984).

Berdasarkan hasil analisa menunjukkan bahwa besarnya biaya pada masing-masing alat tangkap berbeda-beda. Di Kabupaten Subang (Jawa Barat) biaya tetap khususnya untuk biaya penyusutan adalah trammel net sebesar Rp.2.579.996,- jaring arad sebesar Rp. 1.994,996,- dan jaring rampus sebesar Rp. 2.329,996,- per tahun. Untuk biaya administrasi (SIUP/SIKP, Pas Biru dan biaya administrasi masing-masing alat tangkap Rp. 75.000 ,- pertahun, begitu pula untuk biaya pemeliharaan dan perawatan yang harus dikeluarkan pemilik untuk alat tangkap trammel net Rp. 2.184.000,- jaring arad sebesar Rp. 1.700.000,- dan jaring rampus sebesar Rp. 1.676.000,- Sedangkan biaya tidak tetap untuk jaring trammel net sebesar Rp. 2.357.100,-, jaring rampus sebesar Rp. 2.850.000,- dan jaring arad sebesar Rp. 3.432.000,- per tahun.
Di Kabupaten Gresik (Jawa Timur) biaya tetap khususnya biaya penyusutan sebesar Rp. 4.656.670,- per tahun, sedangkan biaya tidak tetap sebesar Rp.3.647.990,- pertahun. Khusus di Kabupaten Gresik jenis alat tangkap yang diusahakan yaitu trammel net.

Di Kabupaten Demak (JawaTengah ) biaya tetap yaitu biaya penyusutan untuk alat tangkap jaring trammel net sebesar Rp. 2.554.580,- dan jaring arad sebesar Rp. 2.010.830,- per tahun. Sedangkan biaya pemeliharaan untuk trammel net sebesar Rp.600.000,- untuk jaring arad sebesar Rp. 1.980.000,- dan biaya administrasi masingmasing Rp.75.000,- per tahun. Sedangkan biaya tidak tetap untuk trammel net sebesar Rp. 3.891.500,- dan jaring arad sebesar Rp.2.841.720,- pertahun. Di Kabupaten Pati, biaya penyusutan sebesar Rp. 2.075.000,biaya perawatan Rp. 1.575.000,- per tahun. Sedangkan biaya tidak tetap sebesar Rp. 1.944.000,- pertahun.

\section{Penerimaan}

Dari perhitungan hasil tangkapan dan harga jual diperoleh hasil raman kotor. Di Kabupaten Subang (Jawa Barat) hasil raman kotor untuk hasil tangkapan trammel net sebesar Rp. 19.400.000,- jaring rampus sebesar Rp.15.625.000,- dan jaring arad sebesar Rp.17.500.000,- per tahun. Setelah dipotong retribusi $5 \%$ maka diperoleh penerimaan untuk jaring trammel net sebesar Rp.18.430.000,- jaring rampus sebesar Rp.14.843.750,- dan jaring arad sebesar Rp.16.625.000,- per tahun. Sedangkan penerimaan bersih per unit penangkapan setelah dikurangi dengan biaya ekploitasi maka jaring trammel net sebesar Rp.2.357.100,-, jaring rampus sebesar Rp. 2.850.000,-dan jaring arad sebesar Rp.3.432.000,- per tahun maka diperoleh hasil bersih untuk jaring trammel net Rp. 16.072.900,- jaring rampus sebesar Rp.11.993750,- dan jaring arad Rp. 13.193.000,-, pendapatan tersebut merupakan pendapatan bersih per unit usaha per tahun sebelum bagi hasil.Berdasarkan bagi hasil yang berlaku maka bagi hasil dibagi lima bagian yaitu kapal alat dan mesin 3 bagian, pemilik 1 bagian dan pendega 1 bagian. Dari bagi hasil ini menunjukkan bahwa untuk trammel net bagian kapal, mesin dan alat sebesar Rp. 9.643.740, pemilik 3.214.580,dan pendega Rp.3.214,580,-. Total pendapatan nelayan per tahun sebesar $\mathrm{Rp}$. 3.311.580,- dan total pendapatan pemilik pertahun sebesar Rp. 8.116.324,- rentabilitas 
$88,52 \%$, dan RC ratio 2,2 . Sedangkan untuk alat tangkap jaring arad bagian kapal, mesin dan alat sebesar Rp.7.915.800,-, pemilik Rp. 2.638.600,-, pendega Rp. 2.638.600,-. Total pendapatan nelayan per tahun sebesar $\mathrm{Rp}$. 2.721.725,- dan total pendapatan pemilik pertahun Rp. 8.116.324,- rentabilitas 81,93\%, dan $\mathrm{R} C$ ratio 1,8 . Pada jaring rampus bagian kapal,mesin dan alat sebesar Rp. 7.196.250,-, pemilik Rp. 2.398.750,-, pendega Rp. 2.398 .750 ,-. Total pendapatan nelayan per tahun sebesar Rp. 2.476.975,- dan total pendapatan pemilik per tahun Rp. 5.592.129, rentabilitas $64,49 \%$ dan $\mathrm{RC}$ ratio 1,7 .

Di Kabupaten Demak, berdasarkan sistim bagi hasil pada alat tangkap trammel net menunjukkan bahwa pendapatan pemilik sebesar Rp. 2.007.944,- dan penggarap Rp.2.007.944,- sedangkan bagian kapal, mesin dan alat sebesar Rp. 6.023.832,Total pendapatan pemilik sebesar Rp. 8.031.776,- per tahun, rentabilitas $67,06 \%$ dan $\mathrm{RC}$ rasio 1,4. Pada jaring arad menunjukkan bahwa pendapatan pemilik sebesar Rp. 2.644.560,- dan pendega sebesar Rp. 2.644.560,- per tahun, sedangkan bagian kapal, mesin dan alat Rp. 7.933.680,-. Total pendapatan pemilik sebesar Rp.10.578.240,-, rentabilitas 73,28 \% dan $\mathrm{RC}$ rasio 1,9

Di Kabupaten Pati, pendapatan pemilik dan pendega untuk alat tangkap trammel net masing-masing sebesar Rp. 3.120.000,-per tahun, sedangkan untuk kapal, alat dan mesin sebesar Rp. 9.361.500,-. Total pendapatan pemilik sebesar Rp. 12.482.000,-, rentabilitas $105,77 \%$ dan $\mathrm{RC}$ rasio 2,7 . Di Kabupaten Gresik pendapatan pemilik sebesar Rp. 2.728.420,- dan pendega Rp. 2.728.420,- per tahun, sedangkan bagian kapal, alat dan mesin sebesar Rp. 8.185.260,maka total pendapatan pemilik sebesar Rp. 10.853.680,- per tahun. Rentabilitas 38,02\% dan $R C$ rasio 1,3 .

Dari uraian diatas dapat disimpulkan bahwa usaha penangkapan udang penaeid di pantai utara Jawa dengan menggunakan beberapa jenis alat tangkap udang (trammel net, arad dan rampus) dapat memberikan prospek perkembangan usaha yang cukup potensial untuk dikembangkan. Hal ini terlihat dari tingkat ratio antara penerimaan dan biaya yang berada diatas nilai 1 untuk seluruh alat tangkap serta nilai rentabilitas ekonomi yang berada diatas suku bunga Bank > $24 \%$. Permasalahan yang timbul adalah tidak adanya sistem pemasaran yang kompetitif sehingga pemasaran udang ini masih bersifat monopolistik atau oligopolistik, adanya sistim pemasaran semacam ini pendapatan nelayan sulit untuk ditingkatkan.

\section{Pemasaran}

\section{Struktur pasar}

Kecuali di Subang, produksi udang penaeid di daerah penelitian lainnya (Demak, Pati dan Gresik) didistribusikan langsung ke pedagang pengumpul tanpa melalui TPI. Orientasi pemasaran udang penaeid ini adalah ekspor sehingga tidak pernah terlihat produksi udang penaeid khususnya untuk jenis udang penaeid ukuran ukuran tertentu dipasarkan di pasarpasar lokal.

Gambar 2 terlihat bahwa saluran pemasaran udang penaeid di pantai utara Jawa, hampir semua nelayan menjual udangnya melalui bakul dan pedagang pengumpul yang biasanya berdomisili di desa pantai (produsen). Dengan demikian peranan bakul dan pedagang pengumpul sangat penting dalam menentukan distribusi udang penaeid.

Prosentase udang penaeid yang didistribusikan oleh berbagai lembaga pemasaran diperkirakan sebagai berikut $40 \%$ nelayan yang memasarkannya melalui lelang dan sisanya $60 \%$ menjual udangnya langsung ke pedagang bakul atau pedagang pengumpul. Dari pedagang pengumpul udang yang telah disortir disortir sesuai dengan ukurannya didistribusikan ke pedagang besar yang selanjutnya langsung mendistribusikan/ mengirimkan ke eksportir. Pedagang pengecer mengambil dari pedagang bakul dan mendistribusikannya ke konsumen melalui pasar-pasar lokal sekitarnya dengan prosentase yang sangat terbatas.

Meskipun ada nelayan yang menjual hasil produksi udangnya melalui sistim lelang, bila dilihat dari srtuktur pasar yang berlaku khususnya ditingkat produsen terbentuk struktur pasar yang oligopsonistik begitu pula bagi nelayan yang menjual langsung ke pedagang pengumpul atau bakul juga akan membentuk struktur pasar yang oligopsonistik pula. Hal ini terlihat dari proses lelang yang menunjukkan bahwa empat sampai lima pedagang terbesar sudah menguasai lebih dari $90 \%$ produksi udang yang dilelang. Akibatnya nelayan tidak mendapatkan harga 


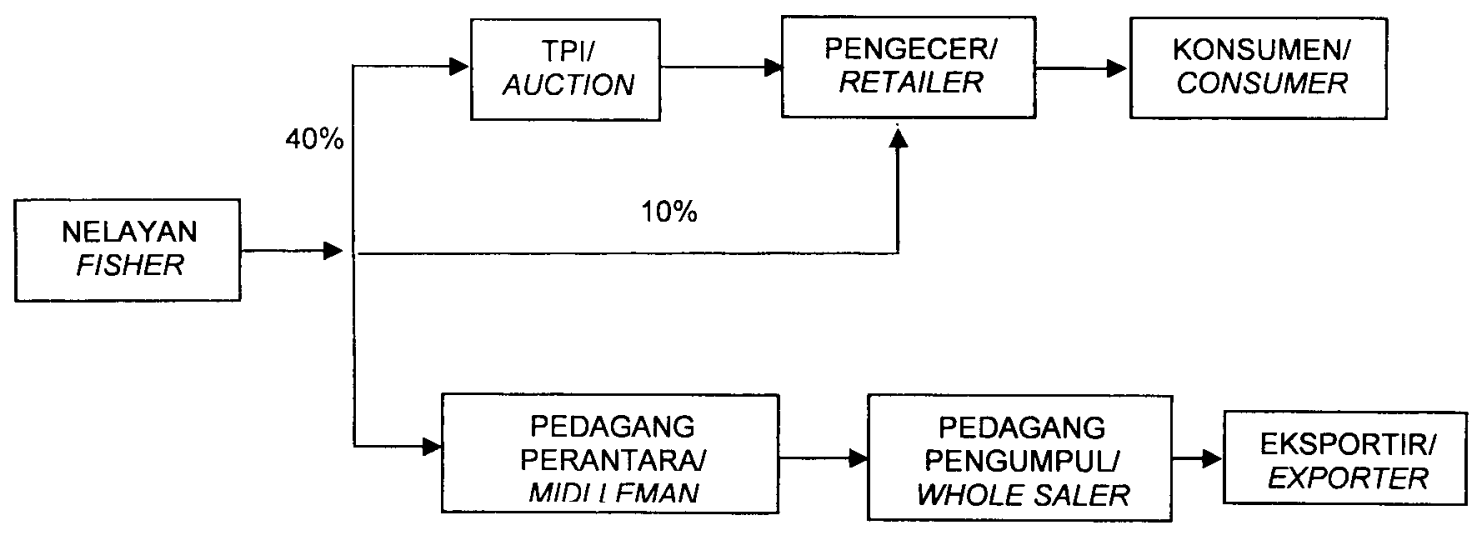

Gambar 2. Distribusi pemasaran udang penaeid di utara Jawa

Figure 2. Marketing distribution of shrimp in north Java

jual yang pantas. Pada lembaga pemasaran di tingkat pedagang besar justru membentuk struktur pasar yang mengarah pada monopolistik. Hal ini kemungkinan terjadi karena jenis komoditi yang diperdagangkan yaitu udang memiliki nilai jual yang sangat tinggi sehingga mendorong pemilik modal baik yang berada di tingkat produsen maupun ditingkat pedagang besar bermain untuk menguasai pasar udang di tingkat nelayan. Masalah ini menjadi lebih buruk karena nelayan tidak punya alternatif lain dalam memasarkan hasil. Tempat Pelelangan Ikan yang diharapkan dapat meningkatkan harga jual tidak berpihak ke nelayan. Akibatnya sebagian besar nelayan tidak menjual hasil tangkapannya melalui TPI. Hal ini dapat dibuktikan dari Sensus Pertanian 1993 bahwa di tingkat nasional $61 \%$ nelayan menjual hasil tangkapannya diluar TPI dan hanya $21 \%$ yang menjual melalui TPI sisanya di jual di laut dan lain-lain. (Badan Pusat Statistik, 1997). Gambaran tersebut menunjukkan bahwa keberadaan TPI belum berfungsi secara optimal sesuai dengan tujuan pembentukannya.

\section{Perilaku pasar}

Bain (1968) dalam Nikijuluw dan Basuki (1991) mendefinisikan perilaku pasar sebagai pola para pelaku pasar dalam menyesuaikan diri dengan perubahan yang terjadi. Aspek yang diamati adalah kebijaksanaan penentuan harga dan praktek pedagang sebagai respon atas perubahan pasar. Hasil penelitian menunjukkan bahwa ditingkat produsen harga ditetapkan oleh pembeli, tidak terjadi tawar menawar antara penjual dan pembeli. Nelayan tidak mempunyai kemampuan untuk mengadakan tawar menawar. Meskipun nelayan menjualnya melalui lelang, tawar menawar yang terjadi hanya sebatas formalitas sedangkan harga sudah ditentukan sebelumnya. Terjadinya proses tawar menawar hanya diantara pedagang dan konsumen di pasar eceran.

Proses distribusi udang dari nelayan ke bakul maupun pedagang pengumpul dilakukan setiap hari tanpa melalui proses pemisahan (sortir) sesuai dengan jenis dan ukurannya. Pada tingkat pedagang besar sortir dilakukan dan harga jual disesuaikan berdasarkan jenis dan ukurannya. Pedagang pengumpul mengirimkan udang ke pedagang besar tergantung pada tersediaanya udang di nelayan biasanya dua hari sekali pengiriman dilakukan pada tingkat pedagang besar dengan perlakuan khusus seperti terjaganya suhu maupun pengepakan dalam stereofoam yang baik sehingga kelangsungan mutu udang masih tetap terjaga.

\section{Keragaan pasar}

Bain (1968) dalam Nikijuluw dan Basuki, (1991) mendifinisikan bahwa keragaan pasar sebagai kulminasi akhir yang dicapai oleh perusahaan atau pengusahan yang terlibat. Dalam pemasaran konsep yang relevan untuk menganalisa keragaan pasar melalui analisa penyebaran harga (farm retail spread) dengan menghitung marjin pemasaran. Dahl dan Hamond (1977) dalam Saptana dan Noekman (1994) menyatakan bahwa marjin pemasaran mengambarkan perbedaan harga yang dibayarkan konsumen dari harga-harga yang diterima produsen. Didalam marjin tataniaga terdapat komponen biaya pemasaran (marketing cost) yang dikeluarkan oleh 
Tabel 2. Analisis marjin tataniaga udang penaeid di pantai utara Jawa $(\mathrm{Rp} / \mathrm{Kg})$

Table 2. Analysis marketing margin of shrimp in north coast of Java (Rp/Kg)

\begin{tabular}{|c|c|c|c|c|c|c|c|}
\hline \multirow[b]{3}{*}{ Uraian } & \multicolumn{7}{|c|}{ Kabupaten/Regency } \\
\hline & \multicolumn{2}{|c|}{ Subang } & \multicolumn{2}{|c|}{ Demak } & \multicolumn{2}{|c|}{ Pati } & \multirow{2}{*}{$\begin{array}{c}\text { Gresik } \\
\text { U.jerbung } \\
\text { IP.mer- } \\
\text { guensis }\end{array}$} \\
\hline & $\begin{array}{l}\text { U.jerbung } \\
\text { IP.mergu } \\
\text { ensis }\end{array}$ & $\begin{array}{c}\text { U.krosok } \\
\text { IMetapen } \\
\text { aeusen } \\
\text { sis } \\
\end{array}$ & $\begin{array}{l}\text { U.jerbung } \\
\text { IP.mergu- } \\
\text { ensis }\end{array}$ & $\begin{array}{l}\text { U.dogol } \\
\text { IM. Ele- } \\
\text { gans }\end{array}$ & $\begin{array}{l}\text { U.jerbung } \\
\text { IP.Mergu } \\
\text { ensis }\end{array}$ & $\begin{array}{l}\text { U.krosok } \\
\text { IMetepe- } \\
\text { naeus } \\
\text { ensis }\end{array}$ & \\
\hline 1 & 2 & 3 & 4 & 5 & 6 & 7 & 8 \\
\hline $\begin{array}{l}\text { Nelayan (Fisherman): } \\
\text { Harga jual/ Salling price } \\
\text { (Rp/Kg) }\end{array}$ & 15.000 & 5.000 & 50.000 & 40.000 & 80.000 & 18.000 & 60.000 \\
\hline \multicolumn{8}{|l|}{$\begin{array}{l}\text { Pedagang perantara } \\
\text { (Middleman): }\end{array}$} \\
\hline $\begin{array}{l}\text { Harga beli } \\
\text { (Purchasing Price) }\end{array}$ & 15.000 & 5.000 & 50.000 & 40.000 & 80.000 & 18.000 & 60.000 \\
\hline $\begin{array}{l}\text { Biaya pemasaran } \\
\text { (Marketing Cost) }\end{array}$ & 800 & 500 & 5.000 & 5.000 & 500 & 200 & 2.000 \\
\hline $\begin{array}{l}\text { Harga jual (Salling } \\
\text { Price) }\end{array}$ & 25.000 & 10.000 & 60.000 & 47.500 & 87.500 & 21.000 & 80.000 \\
\hline $\begin{array}{l}\text { Marjin pemasaran } \\
\text { (margin) }\end{array}$ & 10.000 & 5.000 & 10.000 & 7.500 & 7.500 & 3.000 & 20.000 \\
\hline Laba (Earning) & 9.200 & 4.500 & 5.000 & 2.500 & 7.500 & 2.800 & 18.000 \\
\hline \multicolumn{8}{|l|}{$\begin{array}{l}\text { Pedagang pengumpul } \\
\text { (Wholesaler) }\end{array}$} \\
\hline $\begin{array}{l}\text { Harga beli (Purchasing } \\
\text { price) }\end{array}$ & 25.000 & 10.000 & 60.000 & 47.500 & 87.500 & 21.000 & \\
\hline $\begin{array}{l}\text { Biaya pemasaran } \\
\text { (Marketing price) }\end{array}$ & 2.000 & 1.200 & 10.000 & 10.000 & 1.000 & 800 & \\
\hline $\begin{array}{l}\text { Harga jual (Salling } \\
\text { price) }\end{array}$ & 40.000 & 17.500 & 77.500 & 60.000 & 100.000 & 25.000 & \\
\hline $\begin{array}{l}\text { Marjin pemasaran } \\
\text { (Margin) }\end{array}$ & 15.000 & 7.500 & 17.500 & 12.500 & 12.500 & 4.000 & \\
\hline Laba (Earning) & 13.000 & 6.300 & 7.500 & 2.500 & 11.500 & 3.200 & \\
\hline \multicolumn{8}{|l|}{ Pengecer (Retailler) } \\
\hline $\begin{array}{l}\text { Harga beli } \\
\text { (Purchasing price) }\end{array}$ & 15.000 & 5.000 & 50.000 & 40.000 & 87.500 & 21.000 & \\
\hline $\begin{array}{l}\text { Biaya pemasaran } \\
\text { (Marketing Cost) }\end{array}$ & 800 & 500 & 5.000 & 5.000 & 500 & 200 & \\
\hline $\begin{array}{l}\text { Harga jual (Salling } \\
\text { Cost) }\end{array}$ & 25.000 & 15.000 & 60.000 & 47.500 & 92.500 & 27.500 & \\
\hline $\begin{array}{l}\text { Marjin pemasaran } \\
\text { (Margin) }\end{array}$ & 10.000 & 10.000 & 10.000 & 7.500 & 5.000 & 6.500 & \\
\hline Laba (Earning) & 9.200 & 9.500 & 5.000 & 2.500 & 4.500 & 6.300 & \\
\hline \multicolumn{8}{|l|}{$\begin{array}{l}\text { Konsumen } \\
\text { (Consumer) }\end{array}$} \\
\hline $\begin{array}{l}\text { Harga beli (Purchasing } \\
\text { price) }\end{array}$ & 25.000 & 15.000 & 60.000 & 47.500 & 92.500 & 27.500 & \\
\hline
\end{tabular}


lembaga pemasaran dan keuntungan (marketing profit) yang diterima oleh lembaga niaga.

Tabel 2 menunjukkan bahwa marjin pemasaran pada setiap lembaga pemasaran yang terjadi disetiap daerah relatif sama besar sesuai dengan jenis udang yang dipasarkan.Di Subang untuk jenis udang jerbung marjin pada setiap lembaga pemasaran berkisar antara Rp.10.000,-/kg sampai Rp.15.000,-/kg dan lembaga pemasaran pedagang pengumpul memperoleh marjin terbesar yaitu Rp.15.000,-/kg. Sedangkan pada jenis udang krosok marjin pemasaran berkisar antara Rp. $5.000,-/ \mathrm{kg}$ sampai $\mathrm{Rp}$. $10.000,-/ \mathrm{kg}$ dan lembaga pemasaran pedagang pengecer memperoleh marjin terbesar yaitu Rp.10.000,- $/ \mathrm{kg}$. Di Demak untuk jenis udang jerbung marjin pemasaran terbesar diperoleh pedagang pengumpul sebesar Rp. 17.000,-/kg, dengan sebaran marjin pemasaran pada setiap lembaga pemasaran berkisar antara Rp.10.000,-/kg sampai Rp.17.500,-/kg. Untuk udang dogol marjin terbesar diperoleh pedagang pengumpul yaitu Rp.12.500,-/kg, dengan sebaran marjin pemasaran pada setiap lembaga pemasaran berkisar Rp.5.000,-/kg sampai Rp.12.500,-/kg. Sedangkan di Pati untuk jenis udang jerbung marjin terbesar diperoleh pedagang pengumpul yaitu Rp.12.500,-/kg untuk jenis udang krosok marjin terbesar diperoleh pedagang pengecer yaitu Rp. 6.500,-/kg. Di Gresik untuk jenis udang jerbung marjin terbesar diperoleh pedagang perantara sebesar Rp.18.000,-/kg .

Sistem distribusi pemasaran udang penaeid di pantai utara Jawa yang terjadi menunjukkan bahwa marjin pemasaran terbesar pada setiap lembaga pemasaran dibeberapa daerah pada umumnya dinikmati oleh pedagang pengumpul. Hal ini wajar mengingat di tingkat lembaga pemasaran inilah mulai dilakukan suatu pemisahan dan pengelompokan (sortir) terhadap setiap jenis udang sesuai dengan ukuran sehingga perbedaan harga jual yang cukup tinggi terjadi pada lembaga pemasaran ini.

\section{KESIMPULAN}

Tingkat pemanfaatan udang penaeid belum optimal, rata-rata pemanfaatannya berkisar antara $28 \%-79 \%$ yang berarti bahwa pengembangan penangkapan masih memungkinkan dilakukan, dengan cacatan tanpa merusak lingkungan sumberdaya udang. Untuk pengaturan alat tangkap yang selektif didikuti dengan aturan-aturan formal dan informal dalam masyarakat nelayan sangat diperlukan.

Meskipun usaha penangkapan udang penaied di pantai utara Jawa berdasarkan kajian analisis ekonomi dapat memungkinkan untuk dikembangkan, namun masih belum memberikan jaminan kesejahteraan yang lebih baik khususnya bagi nelayan penggarap. Banyak faktor yang mempengaruhinya antara lain :

(a). Tidak berperannya TPI sebagai tempat menstabilkan dan meningkatkan harga jual. Hal ini disebabkan karena masih dominannya pengaruh dari pedagang pengumpul yang menguasai mekanisme pasar, akibatnya harga ditentukan sepihak oleh pedagang. Ini terlihat dari bentuk pemasaran yang mengarah pada struktur yang oligoplistik. Untuk itu perlunya dibentuk model pengembangan bisnis senter yang melibatkan berbagai pihak yang dapat menjadi alternatif baru dibidang pemasaran udang khususnya dan hasil perikanan laut umumnya.

(b). Sistim upah dengan sistim bagi hasil yang berlaku saat ini masih belum berpihak kepada nelayan penggarap. Ketentuan yang berlaku dalam sistim bagi hasil masih ditentukan sepihak oleh pemilik. Semangat pembagian hasil masih jauh dari rasa keadilan, sehingga hak penggarap adakalanya diabaikan sehingga tidak memiliki kedudukan hukum yang kuat. Untuk peningkatan pendapatan adanya diversivikasi alat tangkap perlu dilakukan. Disamping itu pula upah dengan sistim gaji perlu dikaji lebih mendalam.

\section{DAFTAR PUSTAKA}

Aziz, Ki Agus, 1996. "Pukat Harimau" sebagai salah satu alat pemanfaatan sumberdaya perikanan. Makalah disampaikan dalam diskusi ilmiah pemanfaatan sumberdaya ikan di ZEEI dan permasalahan "Pukat Harimau" di Indonesia. Fakultasperikanan IPB dan Jaringan Kerja Riset Teknologi Penangkapan Ikan Indonesia, 8 Januari. $9 \mathrm{p}$.

Huda, K dan Hendra, D. 2000. Penangkapan udang dan ikan demersal di utara Jawa. 
Laporan praktek lapang. Balitkanlut Jakarta. 15 p.

Nikijuluw, V. dan Basuki, R. 1991. Pemasaran Ikan Laut di Kalimantan Selatan. Proseding Temukarya IImiah Perikanan Rakyat, Jakarta. p. $663-640$

Nurani, Tri Wiji. 1991. Sistem bio-tekhnico-socioeconomic usaha pengelolaan sumberdaya perikanan laut. Buletin PSP Vol.3(1):1-15.

Priyanti, A., Sabrani, M., Hariyanto, B., Wisnunugroho, M. dan Sudaryanto, B. 2000. Analisis ekonomi usaha ternak sapi menunjang sistem IP Padi 300. Prosiding Seminar Nasional Peternakan dan Veteriner.Pusat Penelitian dan
Pengembangan Peternakan, Bogor :485-493.

Saptana dan Noekman. 1994. Kajian aspek produksi dan pemasaran jeruk pada lahan pasang surut dan lahan kering di Sulawesi sealatan (Kasus di Kabupaten Luwu dan Selayar). Forum Agro Ekonomi Vol.12(1):1429

Kesteven, G.L. 1973. Manual of fisheries science. Part 1. An introduction to fisheries science. FAO Fisheries technical paper No. 118. FAO. Rome: 43 p.

Nikijuluw, V. PH, (1984) Analisis Biaya dan Penerima alat tangkap Trammel Net di Batang, Jawa Tengah, L.P.P.L .No.33. p. 21-30 
